\title{
The diakonia of Practical Theology to the alienated in South Africa in the light of 1 Peter
}



This article investigates the role that Practical Theology can play in addressing the problem of alienation amongst the people of South Africa. The investigation is conducted from the viewpoint of the biblical concept of diakonia (service work). This concept as well as the content of Practical Theology as it is found in the first letter of Peter is investigated with the purpose of elucidating the diakonia of Practical Theology with regard to alienation. Four questions are answered in the article:

- What may some of the reasons why people in South Africa experience alienation be?

- What significance do the results of the most recent research into the diakon word group have for the diakonia of Practical Theology?

- What insight can be gained from 1 Peter into the diakonia of Practical Theology for people who may be experiencing alienation in South Africa?

- What should the diakonia of Practical Theology in the light of 1 Peter be for people who experience alienation?

Intradisciplinary and/or interdisciplinary implications: This article addresses the issue of alienation. This is an issue that also falls within the research field of sociology and psychology. This article wants to make a contribution from a biblical perspective using the exegesis of a New Testament letter $(1 \mathrm{Pt})$ with the focus on 1 Peter 4:10 and the use of the diakon word group in the letter. The article thus also operates on the research field of New Testament Theology. The results of the exegesis are used to give guidelines for the diakonia of Practical Theology in South Africa. The article challenges the way some research in Practical Theology is done, not using the Bible as reference point, thus making the distinction between Practical Theology and sciences like sociology and psychology indistinct.

\section{Introduction}

The aim of this article is to investigate the diakonia (service) that can be provided by Practical Theology to address the problem of alienation ${ }^{1}$ in South Africa (Janse van Rensburg \& Pienaar 2005).

Since the general election of 1994 and the accompanying birth of the 'New South Africa', much has been written concerning forgiveness and reconciliation in South Africa. Several scientific articles have been written in which special attention is given to the evaluation and/or lack of success of the Truth and Reconciliation Commission (Barry 2006; Leer-Salvesen 2009; Shriver 2007; Vorster 2009; Vosloo 2001). In some of these articles, the issue of reconciliation and alienation is touched upon (Cilliers 2013; Danaher 2007; Maluleke 2005; Meijers 2009; Meiring 2009). Frequent references are made to scripture. Only one article focuses primarily on the feeling of alienation amongst inhabitants and bases its arguments on an in-depth exegesis of a scriptural part, namely that of Janse van Rensburg and Pienaar (2005). However, the authors are only concerned with the experience of the Afrikaner and do not address the plight of other groups. I am convinced that the feeling of alienation plays an important role in the anxiety and discouragement that prevail in South Africa today and that practical theological research may provide a particular service in this bleak situation. Yet, no research has focused on feelings of alienation from a practical theological viewpoint. This article is an effort to address this gap.

The population of South Africa is made up of a rich diversity of groups. The different groups are mainly differentiated by race, gender, culture, socio-economic circumstances, trauma and religion, country of origin, language, training and academic qualifications.

This article endeavours to provide answers to the following questions:

- What may some of the reasons why people in South Africa experience alienation, be?

1.In this article alienation is seen as the experience of being treated as if you do not fully belong and/or are being rejected and not receiving what is rightfully due to you; the state of being an outsider or the feeling of being isolated and discriminated against. 
- Are there people in South Africa who experience alienation and what may some of the reasons for this alienation be?

- What significance do the results of the most recent research into the diakon word group have for the diakonia of Practical Theology?

- What insight can be gained from 1 Peter into the diakonia of Practical Theology to people who may be experiencing alienation in South Africa?

- What should the diakonia of Practical Theology in the light of 1 Peter be to people who experience alienation?

In the first place, some of the reasons why people in South Africa experience alienation will be discussed.

The second part of this article presents a summary of the results of the most recent research into the diakon word group (Arndt, Danker \& Bauer 2000; Breed 2012a, 2012b, 2013; Collins 1990, 1992, 1995, 2002a, 2002b, 2005, 2010, 2012; Gooder 2006; Haire \& Watson 2003:40-51; Hentschel 2007; Latvus 2008, 2010), and more specifically, 1 Peter as applicable to the research question.

Next, 1 Peter will be examined to deduce guidelines that are applicable to the field of research. For this purpose, the historical-grammatical method of exegesis will be used. The research concentrates on service work - 1 Peter 4:10 - which describes the service work (diakonia) of the believers and this is taken as the focus point in studying 1 Peter. This verse is deliberately chosen in search of an answer to the research question, which is the following: What could Practical Theology contribute to a situation in which fewer people in South Africa would experience alienation from the country and its people and thus contribute to motivate inhabitants to make a positive contribution to the country?

In the final section of the article, the diakonia of Practical Theology will be investigated. Based on the findings regarding that point, an answer will be given to the question on the service work of Practical Theology in South Africa.

In the following section, possible causes for a feeling of alienation amongst people in South Africa are investigated. Because of the scope of this article, only a few causes will be discussed.

\section{Some of the reasons for the feeling of alienation in South Africa'}

Different groups and individuals in the South African society experience something of this alienation - each group and everyone in a unique way. The white group experiences alienation that flows, amongst other reasons, forth from affirmative action, for example when someone is overlooked for promotion for which he or she is apparently the best candidate (Goldin 2002; Griffiths 2007; Marchetti-Mercer 2012). The coloured and Indian people experience alienation 2.It is not in the scope of this article to give a detailed analysis of the reasons for alienation. in that they sometimes feel they are not black enough and therefore they do not benefit fully from affirmative action. Further reasons are that they are not truly integrated into the broad population because of their social circumstances and even because of their unique languages. Black people experience alienation because the broad population's expectations of events in South Africa after 1994 were not realised (Chiloane-Tsoka 2012; Ponte, Roberts \& Van Sittert 2007). Many who benefitted from land reform could not make a success of farming (Moobi \& Oladele 2012). Some who were appointed in positions for which they did not have the necessary experience are severely criticised in the media and are even on the receiving end of the contempt of their fellow-employees (Akinboade, Kinfack \& Mokwena 2012; Koelblea \& LiPumab 2010). Thousands of people coming from other African countries to South Africa for work opportunities live under the dark cloud of xenophobia which flames up continually (Jeffrey 2010; Ilo 2009). The church has lost its privileged position in society in South Africa and is experiencing severe criticism for mistakes they made in past and current decisions, internal divides and the lack of involvement in society (Charles 2010; Haddad 2005). Individuals suffer the pain of alienation from the country and its people because of trauma and violence. ${ }^{3}$

This alienation frustrates people and frequently leads to conflict. Williams (2012:38, 39) defines social conflict as, 'the strategic interaction between individuals or groups which results from a (perceived) deprivation by an interdependent other.' The feeling of victimisation or deprivation (alienage) may also develop into conflict with those on whom you are dependent for providing that of which (according to your perception) you are deprived.

Each of these groups finds itself in an environment where people talk of other people and situations in a negative and bitter manner, even with hate. If Christians do not share in the same negativity or participate in the different ways of protest, they may be seen as strangers or as traitors. It makes them aliens in the sense of the concept in 1 Peter. It is clear that believers from each of the above-mentioned and other groups may find themselves in a situation (where they feel alienated) similar to that of the addressees of 1 Peter. Therefore, the equipment provided in 1 Peter may also be suitable for many people in South Africa who are feeling alienated.

In the second place, existing research on the diakon word group is scrutinised.

\section{Diakonia}

\section{Results of most recent research}

In previous articles and papers (Breed 2012a, 2012b, 2013; Breed \& Breed 2010; Breed \& Du Plessis 2012), I have not only presented the results of the most recent research on the meaning of the diakon word group in the New Testament, but 3.For an in-depth discussion of the impact of trauma in the South African context see Botha (2004). 
I also carried out further research on the topic. In this section, all the relevant results from the above-mentioned sources will be presented. Together with this summary, the meaning of the New Testament word group in 1 Peter 4:10 will be investigated and applied to the subject of the article, namely the diakonia of Practical Theology to the alienated in South Africa. In contrast to the conviction that the diakon word group expresses humble charity as service to people, it has become clear from the research that the word group denotes a much wider range of meanings and that it is not primarily a verbalisation of charity or service to people. The word group is used in the New Testament to express a service work performed on behalf of someone who has commissioned that work of service. The Commissioner or commissioner in the New Testament is usually God or a congregation that sends someone out in the name of the Lord. Diakonoi perform their diakonia for the benefit of other people, but primarily as a service to God or another commissioner. For this reason, they have to give account of their work to the commissioner. Diakonoi therefore come in the name of their commissioner and the service to other people is primarily a service to God. The content of the service performed must be deduced from the context in which the word group is used, and therefore it may differ every time.

The invariable semantic content of the word group is 'a representative sent with a specific commission'. Jesus performed his diakonia as messenger of his Father; therefore, he performed the works of the Father and spoke the words of his Father (Jn 5:36; 14:24). He did nothing out of his own and the defining motive for his actions was the glorification of the Father. He involved those that followed him in his diakonia so that he could continue his diakonia through them after his ascension.

Whoever wants to serve him (diakoneo) has to follow him, and his diakonos will be where he is. Those who follow him, will be honoured by the Father (Jn 12:26). Those who serve him, share his glory. Diakonoi perform their diakonia, which is commissioned by God, for the benefit of others, with the purpose of glorifying God and with the certainty that God will honour them. Diakonoi do not seek the honour of people and are prepared to lose their life for the diakonia. Diakonia is also aimed at the expansion of the reign of Christ and victory over the evil. Diakonia serves the purpose of people being drawn to Jesus by the gospel of the cross. This happens when people believe the words of God, which he spoke through Christ, and when they accept that the Father sent the Son to the world so that everyone who believes will be saved by his diakonia (Jn 17).

In South Africa, this information is of special significance in Practical Theology with regard to service work that is provided to inhabitants who are experiencing alienation. At the end of the article, a conclusion will be made on this matter, but first of all, the meaning of the diakon word group in 1 Peter 4:10 must be investigated.

\section{Peter 4:7-11}

\section{Background}

This article relies on the research of other authors for the background to the letter. ${ }^{4}$ Views that are shared with other researchers and that are important to this article are the following: 1 Peter shows a typical letter composition. Sufficient proof does not exist to contradict the internal claim that Peter is the author of the letter. The original readers of the letter included both Jews and non-Jews and the letter was probably a circular to several congregations. The addressees are called: 'strangers and pilgrims' (King James Version [KJV]) or 'aliens and strangers' (New International Version [NIV]). Their alienage included that they were not one with the culture in which they lived. It also meant that they did not hold citizenship of the places where they lived, consequently, they were denied certain rights and they were discriminated against (Janse van Rensburg \& Pienaar 2005:28-32). Because many of them had been part of a sinful culture before they had converted to the Christian faith, they did no longer participate in certain practices. Acting in this way was strange to the people amongst whom they lived. Probably that was the reason why they were treated with suspicion, contempt and aggression. All of these things caused suffering in their lives (Achtemeier 2011:76). Peter wrote to them to not only encourage and comfort them in their trying situation, but also to urge them for a special response.

\section{Structure}

Janse van Rensburg (1992:26-41, 2000, 2010, 2011) makes a significant contribution to the analysis of the structure of the letter by explaining the cohesion of its sections. From his analysis, it is clear that the letter consists of a heading (1 Pt 1:1-2), a body (1 Pt 1:3-5:11) and a conclusion (1 Pt 5:11-14). Regarding the body of the letter, the structural analysis leads him to observe that 1 Peter 1:3-12 is not merely an introduction to the letter but that it describes the foundation of all the exhortations made in 1 Peter 3:13-5:11; thus, 1 Peter 1:3-12 forms the encompassing base of the letter. The warnings in 1 Peter 2:11, 12, fall under the encompassing base set out in 1 Peter 1:3-12 and serve as base for the subdivision in 1 Peter 2:13-4:19. Within verses 1 Peter 2:13-4:19 and 3:13-17 the base statement is given. Figure 1 represents this broad cohesion. In Figure 2, the structure of 1 Peter 3:13-4:19 is represented. In 1 Peter 3:134:19 the exhortation made in 1 Peter 2:11, 12 is applied to injustices and victimisation in society. This is also the section in 1 Peter 4:10, 11 - in which the focus of this article can be found.

The representation by Zwemstra (2003:57) of the argument in 1 Peter 2:11-5:7, clarifies the position of 1 Peter 4:7-11 in the subsection 1 Peter 2:11-5:7 even more.

4.For a comprehensive discussion of the genre and the integrity, the situation of the readers, the authorship, literature and composition of the letter, see Elliot (2000:7-304). 


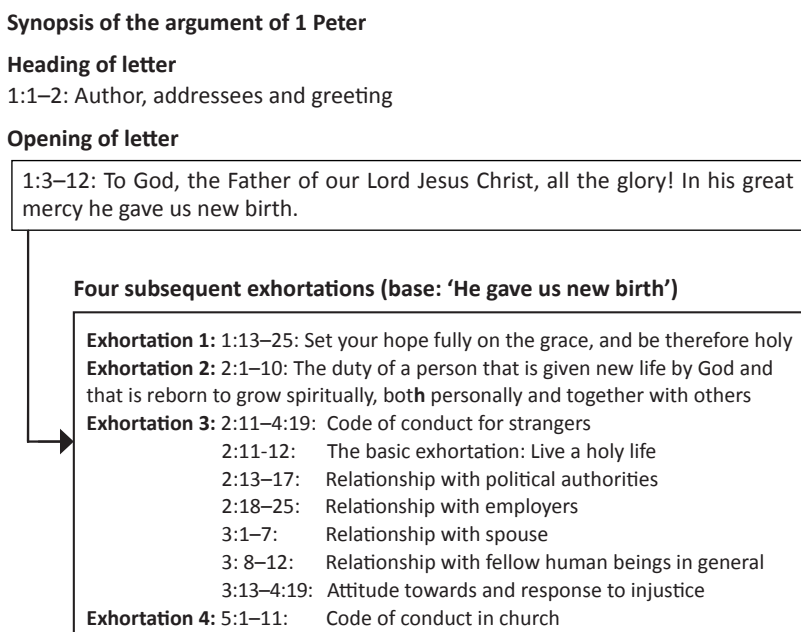

Four subsequent exhortations (base: 'He gave us new birth')

Exhortation 1: 1:13-25: Set your hope fully on the grace, and be therefore holy Exhortation 2: 2:1-10: The duty of a person that is given new life by God and

that is reborn to grow spiritually, both personally and together with others Exhortation 3: 2:11-4:19: Code of conduct for strangers

2:11-12: The basic exhortation: Live a holy life

2:13-17: Relationship with political authorities

2:18-25: Relationship with employers

3:1-7: Relationship with spouse

3: 8-12: Relationship with fellow human beings in general

3:13-4:19: Attitude towards and response to injustice

Exhortation 4: 5:1-11: $\quad$ Code of conduct in church

\section{Conclusion of letter}

5:12-14: Conclusion: Purpose, greetings, conclusion of letter

Source: Janse van Rensburg, J.J, 1992, 'The outline of 1 Peter, a reconsideration', Ekklesiastikos Pharos 74(1), 29- translated

FIGURE 1: Synopsis of the argument of 1 Peter.

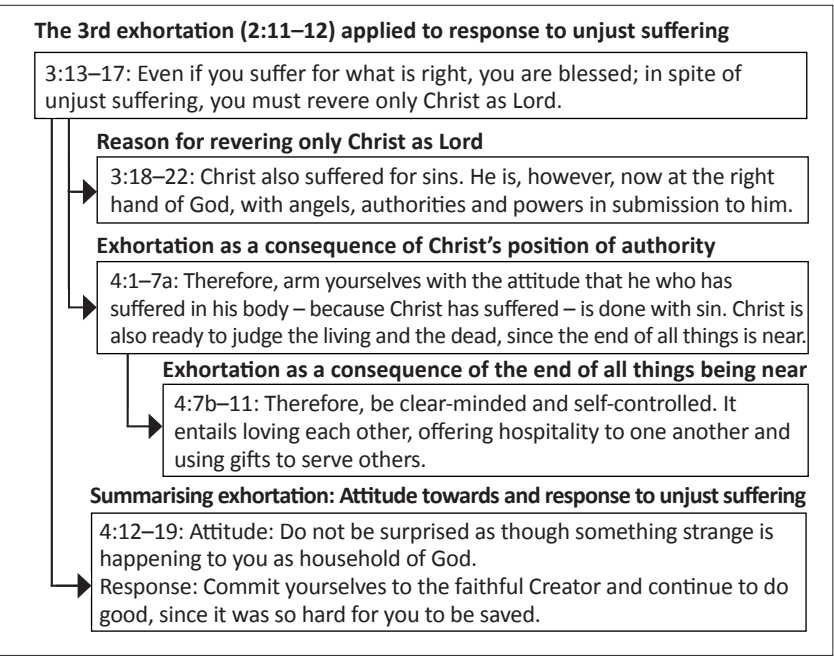

Source: Janse van Rensburg, J.J., 2010, 'Die eskatologie van 1 Petrus: Hoop en vindikasie vir tydelike en permanente uitlanders', In die Skriflig 44(1), 209. http://dx.doi.org/10.4102/ids. v44i1.144

FIGURE 2: Structure 1 Peter 3:13-4:19.

1 Peter 2:11-12: Live a holy life amongst the pagans to the honour of God in the following ways:

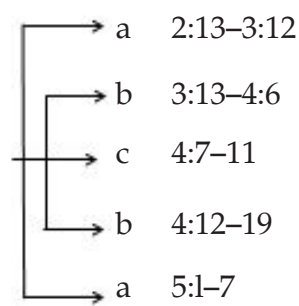

: Show the right attitude towards authority in the world.

: Live a holy life amidst suffering.

: Live a holy life with each other to the honour of God.

: Live a holy life amidst suffering.

: Show the right attitude towards authority in the church.

From this structure, the central position of 1 Peter 4:7-11 is evident, as well as the fact that 1 Peter 4:7-11 clearly points to mutual service in the congregation amidst suffering.

The representation of Clowney (1988:169-188) of the structure of 1 Peter $4: 1-11$ is particularly important to this article, because it emphasises the task of the believer as steward of the grace of God.

1 Peter 4:1-11: The blessing of living as stewards of grace:

4:1 Union with Christ in death to sin.

4:2-6 The liberty of salvation.

4:7 Understanding the time of our stewardship.

4:8-11a Serving in the grace of our stewardship.

4:11b The purpose of our stewardship.

These three divisions (see Clowney 1988:169-188; Janse van Rensburg 1992:29, 2010:209; Zwemstra 2003:57) complement each other to provide a better insight into the meaning of the scriptural part.

\section{Themes}

Researchers indicate several themes that run through 1 Peter. Clowney (1988:177) shows that the exhortation to be 'sober' (KJV) or 'self-controlled' (NIV) is made three times (1 Peter $1: 13 ; 4: 7 ; 5: 8$ ) in the short letter (cf. also Achtemeier 1996:294, 340). Janse van Rensburg (2010:209; see Figure 2) makes it clear that the exhortation to serve each other (1 Peter 4:10) flows forth from the exhortation to be sober (self-controlled) (1 Peter 4:7).

Fagbemi (2009:1-12) argues that the identity of the reader plays an important part in the letter. He reaches the following conclusions:

Identity is a vital aspect of human culture and institution. Identity determines what can be expected of a person, and it dictates how people behave and live their lives. Thus, identity informs character and character defines identity. The same is also true of the early church and its members, not least in 1 Peter where the Christian identity is a central motif that controls the argument of the letter. (p. 12)

Several researchers support this argument. Gupta (2009:62, 63) refers to the cultic metaphors through which Peter reinforced the identity of the readers as God's elect (see also Joseph 2012:69-93) on the one hand and as a missionary community on the other hand (see also Achtemeier 2011:76). Horrel (2007:361-381) discusses the role that the designation christianos (1 Pt 4:16) played in shaping the identity of Christians. The word originated in the contact between the believers and the hostile world (Ac 11:25; Bruce 1990:280, 281). In 1 Peter, the word is used in instructions to believers to show them how they could live up to their identity in a hostile environment (Horrel 2007:381).

Other themes can also be distinguished. The investigation of Williams (2011:78) into the use of the imperative participle in 1 Peter leads him to conclude that the author wanted to guide the readers to a decision of will to embrace a specific conduct. The form the guidance takes varies from a mild warning to a forceful command (see also Joseph 2012:122-147). Slaughter (1995) emphasises the importance to consider the literary argument of the letter. In studying 1 Peter, he discovers the following themes:

- The conduct of the believers - everything that Peter wrote was intended to guide the readers to a specific conduct. 
- The suffering of the believers because of unjust behaviour - the suffering was mainly caused by hurtful remarks and personal attacks (see Joseph 2012:94-121).

- The respectful behaviour of the believers towards everyone - all of the instructions regarding relationships may be summarised by the expression respect for others. This did not mean the believer had to become a weakling who put up with everything from others; to the contrary, he or she suffered because of the strong stand he or she took against certain practices. The believer had to remain respectful, even in the most difficult circumstances, and this respect excluded revenge.

- The believer's motivation by Christ - the believer had to gain strength from what Christ had done (accomplishing complete salvation) and from how he had entrusted everything to his Father during his suffering.

- The believer's expectation of the future glorification (see Joseph 2012:147-171).

Johnson (1997:601) verbalises the missional window that Peter opened to believers saying:

so, Peter cast a vision for them, a vision of missiology that would direct them to their lost world and help them heal it and change it for Christ's sake. (p. 601)

A very important theme emphasised right through the letter is that of the family of God (Green 2007:139). This theme is connected to another feature of the letter, namely that Peter's encouragement of the believers is based on the Old Testament (Hamilton 2010:522). The theme of alienation is closely related to the history narrated in the Old Testament, as well as to the covenant of God (Green 2007:62). McCruden (2005:44-48) points out that Peter used the covenant language to emphasise the identity of the new covenant people, as well as the certainty of God's compassionate presence (McCruden 2005:44, 45). Peter wanted to show that it was clear from Old Testament history that the people of God lived as strangers on earth. Adam lost the living space that God had created for him and Eve; Noah lived as a stranger amongst godless people; Abraham had to migrate and live as an alien and a stranger (Gn 23:4); both Joseph and Moses experienced this alienage; the Israelites lived as aliens in Egypt and in the desert, and even in the land that the Lord had given them were they aliens in the sense that they had to be different from the nations; eventually, they were aliens in exile. Peter proclaimed to the believers that - although they were the new people of God - they would always be aliens on earth. Yet, just as the Lord had repeatedly created living space for Israel, he would also do the same for them. God created the living space for them by giving them a new birth and by providing diakonia to them in a new faith community. Because of what Christ had accomplished and because of whom he was (is), namely, the Lord, they could live in a certain manner. If they lived like that, obedient to the Lord and trusting the Lord to care for them, God would create a new living space for them amidst hardships in the world.

Green (2007:64) says about the letter that it is entirely Godcentric and Christocentric, 'ensuring that the whole life is structured in relation to God's will, mapped according to God's perspective, provisioned and enabled by God, and directed to God's glory.' Peter intentionally compared the lives of the readers to the life of Jesus. He compared both Jesus and the readers to living stones, rejected by people and yet chosen and honoured in the eyes of God (Green 2007:60). In his ministry to the believers in alienage, Peter guided his readers to understand who they were and how they had to live in the light of who God was and what he had done through Christ.

\section{The diakonia of believers according to 1 Peter 4:10, 11}

On the grounds of the above-mentioned structural analyses and discussion of the themes, it may be deduced that 1 Peter 4:7-11 represents both a climax and a turning point in the letter (Clowney 1988:179). In searching for the meaning of the instructions regarding the diakonia of the believers in these verses, all the above-mentioned information must be taken into account.

The focus in verses 7-11 shifts from the believers' relationship with the world to their relationship with each other (Achtemeier 1996:743, 744). In explaining the diakonia, it must be kept in mind that the author was equipping his readers to live in a world full of hardships. Moreover, the pagans amongst whom they lived had to see the life-giving power of God in them and that Jesus was the Lord of the believers. In this respect, verses 7-11 are a summary of the previous instruction. These verses contain the instruction to the believers that they had to make a living space for each other through mutual love, which included forgiveness, hospitality and readiness for service. Their identity as the chosen and pardoned people of God served as motivation to obey the command to serve each other (diakoneo). They were stewards of the rich variety of God's grace. The gifts that God gave them enabled them to manage God's grace in such a manner that the entire congregation would benefit from it. As Green $(2007: 145,146)$ says, the way the grace of God flows through believers to each other is through the diakonia of every believer. In verse 11, the gifts are described in more detail by means of only two examples, namely the service of the Word and the diakonia. The ministry of the Word had to be words of God (compare Jesus' description of his diakonia, amongst others in Jn 12; see Breed 2013). The diakonia had to be performed with the strength of God (1 Pt 4:11). The service to each other constituted an important part of the equipment that Peter gave to the believers for their lives as newly born members of the family of God in a hostile world that treated them as aliens. In their poverty which was caused by suffering, they could serve the wealth of God's kingdom to each other. As is clear from the structure of 1 Peter, these verses $(1 \mathrm{Pt}$ $4: 7-11)$ are enclosed by verses providing equipment to the readers to deal with their alienage (1 Pt 4:1-6, 12-19). Serving each other would equip them to live in such a way that the wealth of God would be manifest in those who did not believe. In this section (1 Pt 4:11-19), the diakonia is very strongly connected to the reciprocal glorification of God and the believer. This close connection between diakonia and the glorification of God and of believers is also found elsewhere (cf. Jn 12:26 ff.; Breed 2013:3; Breed \& Du Plessis 2012:16-18; Hamilton 2010:523). In 1 Peter 5:1-4, we read that 
Peter encouraged the elders to equip the believers for their work of service in their particular circumstances. The elders would have to give account of their service work to the one who had commissioned their diakonia. The verses in 1 Peter 5:1-4 closely resemble the prescription that Jesus gave to his disciples in respect of the leaders putting their service work into practice (Mk 10:42-45). They should not exercise their authority like the rulers of the world, but the one who wants to be the greatest, should become the diakonos of the other, because the Son of man did not come to be served (diakoneo), but to serve (diakoneo), and to give his life as ransom. This comparison makes it clear that there is a close relationship (as in 1 Cor 12) between the grace (charis) of God, the gifts (charisma) of the Spirit and the diakonia as well as the fruit of equipment (Eph 4) and the powerful work of God when diakonia takes place according to his will (1 Cor 12) (Breed \& Du Plessis 2012:12-16; Hamilton 2010:528).

\section{Practical Theology in 1 Peter}

If the content of the letter is compared to Osmer's (2008) model for Practical Theology, 1 Peter is indeed concerned with practical theology. We find the answers to Osmer's four questions in the letter. The question, 'What is going on?', is answered in the letter by a description of the situation in which the readers found themselves. The description has to attest to thorough insight (1 Pt 2:9-20; 3:1-22). The question is briefly answered by the description of the readers as strangers and aliens (1 Pt 1:1; 2:11) and everything else that elucidates the description further (1 Pt 4:1-19). The question, 'Why is it going on?', is answered by a description of the readers' identity as newly born people. Because they were experiencing a radical change in their behaviour, they evoked a negative response from the unbelievers who were governed by their desires (1 Pt 4:4). The question, 'What ought to be going on?', is answered by the application of the Old Testament to the situation of the readers, as well as by the concretisation of the significance of Jesus' reconciliatory work regarding the readers' suffering (1 Pt 2:4-10, 21-25; 3:14-22; 4:1-19). The question, 'How might we respond?', is answered by guiding the readers to understand what their new relationship with God and his people implies as regards their behaviour in their daily lives in and outside the congregation (1 Pt 4:1-5:10).

The following building blocks, on which Peter's practical theology is built, can be identified:

- A thorough insight into the problem situation (strangers and aliens, suffering, temptations and desires that had governed their lives previously).

- Description of the problem situation (suffering because of citizens' status and a life committed to God).

- Description of the relevant revelation of the Triune God, both in the Old Testament and in Jesus Christ (made new by God, Jesus' example in persecution, Jesus as the King, who is coming to judge, the family of God, the will of God in the concrete situation).

- Practical application of the revelation to the problem situation - the meaning of the identity (in Christ) of the readers for their situation (strangers and aliens as a title of honour, an elect royal priesthood, family of God, stewards of God's grace called to diakonia).

- Exhortation of readers to organise their lives according to their identity in Christ (persuasive imperatives, urging on forcefully).

- The place of the congregation and the leaders of the congregation in solving the problem (task of elders).

In the final section of the article, the diakonia of Practical Theology will be investigated. Based on the findings to this point, an answer will be given to the question about the service work of Practical Theology in South Africa.

\section{The diakonia of Practical Theology}

What is the task of Practical Theology with regard to the feeling of alienage in South Africa? Different answers to this question are possible and they may differ largely from each other, depending on what the researcher regards as the primary object of Practical Theology's investigation.

\section{What is Practical Theology?}

Sproul (1997:11-22) distinguishes between theology and religion. To him theology represents a God-centric scientific practice. As opposed to this, stands a man-centred scientific practice. He points out that a development has taken place in the theological sciences, namely that the focus has shifted from the search for the knowledge of God to the study of human behaviour. In line with this development, the names of theological departments of universities have changed to departments of religious sciences. This phenomenon gives rise to the question that theologians have to ask themselves: 'Are you busy with practical theology or practical religious science?'

Sproul (1997:19) sees the man-centred approach in theology as represented in Figure 3.

Against this background, the question arises whether the discovery made in 1 Peter has something to say to the people who are presently experiencing alienation in South Africa. If so, would Peter's practical theology only serve as an example

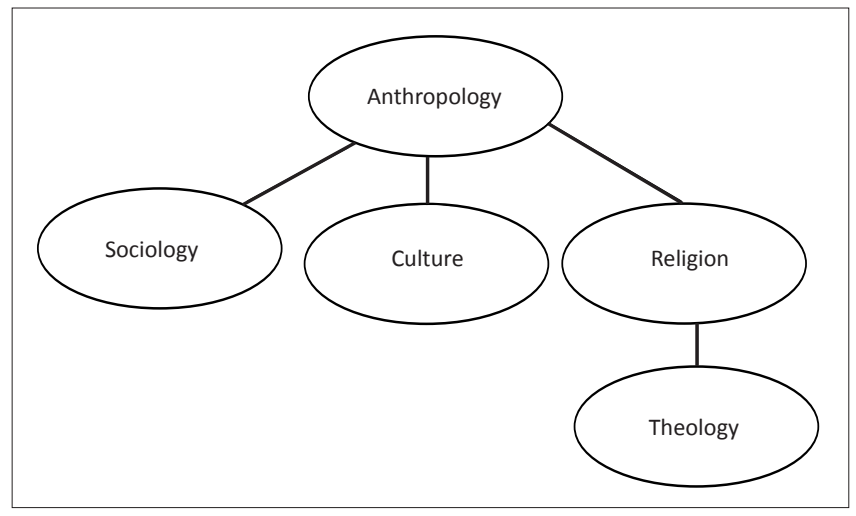

Source: Sproul, R.C., 1997, What is reformed Theology? Understanding the basics, Bake Books, Grand Rapids, p. 19

FIGURE 3: Man-centred view of theology. 
of advice that might be given to people who experience alienation, or could the study of 1 Peter reveal truths that might be applicable to South Africa today? Should one be able to deduce from 1 Peter what the diakonia of practical theology ought to be or would it be merely an example one should take into account?

The question could also be put in another way. Must God play a role in Practical Theology? If not, would it still be honest to speak of theos logos or should a researcher acknowledge that the nature of his field of research is not primarily theology anymore, but anthropology or Bibliology? (Cf. Anderson 2008:26, 27).

Another angle can be applied to Osmer's questions about research methodology, and the following question should then be answered: 'Is it necessary for Practical Theology, if it honestly wants to be theology, to take God and his revelation in the Bible into account when answering Osmer's questions?' Alternatively, could God be used as a mere work hypothesis, as Bonhoeffer says (cf. Anderson 2001:17, n. 11), as an explanation for the inexplicable?

Ray Anderson (2001:11) says in opposition to this, 'before the theologian there was the storyteller.' With this statement, he means that the course that God walked with Abraham, Isaac, Jacob and Joseph was initially communicated orally as the true, concrete actions of the living God with his covenant children. Moses wrote down the theological meaning of God's revelation in this history. Anderson (2001) adds the following in this regard:

What makes theology practical is not the fitting of orthopaedic devices to theoretical concepts in order to make them walk. Rather theology occurs as a divine partner joins us on our walk, stimulating our reflection and inspiring us to recognise the Living Word, as happened to the two walking on the road to Emmaus on the first Easter (Lk 24). (p. 11)

With these comments, he makes it clear that Practical Theology cannot only (according to Osmer's [2008] methodology) study reality ('What is going on?' and 'Why is it going on?'), find a solution ('What ought to be going on?') and arrive at a theory on how to put the solution into practice ('What can we do now?'). To the researcher, truth is not above and independent of reality. The human being does not arrive at the truth of a situation only by means of a theory. God, who lives amongst and in people, who manages and directs everything according to his plan, reveals himself in close communion with the struggling and singing human being, ${ }^{5}$ outside and even despite the theory (Anderson 2001:23). Anderson $(1993: 29,44)$ calls the active involvement of Christ in present times 'Christopraxis'. With this term, he expresses the fact of the reign of the resurrected and glorified Christ in every event. Thus, in order to conduct a complete research, practical theologians ought to remain involved in the situation. The feedback of the people in the situation ought to be an integral part of their research so that they could meet Christ in action. ${ }^{6}$

5.Cf. Louw (1999:15) who says that "God should be interpreted in terms of companionship, partnership and communion'.

6.Cf. Breed and Du Plessis (2012) on 'action orientated research', in which a reevaluation is made of research results, as well as the implementing of adapted o new models on the grounds of feedback from people involved at grass-roots level.
This argument brings pneumatology into the field of vision. The Spirit, who was sent to lead the believer in the full truth, is the one who reveals God's truth in the midst of reality. The Spirit uses the Word to help the believing researchers to understand reality and to think in a new way about their understanding of the Word. Practical Theology draws systematic theology into the life and practice of the Christian community.

When Peter guided his readers in their struggle with their living conditions, his communication with them and his interpretation of their situation took place at several levels. In assessing the situation, he had to display a sensitiveness that would allow the information about the reality to bring him to a deeper insight into the suffering of the readers. Based on his knowledge of the Old Testament and the knowledge that he had received from Jesus, he had to analyse the situation and obtain a clear picture of it. Then he had to find out how he could encourage the readers through the Word and how he could motivate them to live according to the will of God in their suffering. The next step was to write the letter (to have it written) in such a way that the communication between him and the readers would not only be effective and continue to be such, but also that the readers would talk to God about their conditions and about their response to them. After talking to God through his Word and Spirit, they had to talk anew to the people who were causing their suffering. They also had to talk about the economic and other consequences of their alienage (confer Peter's exhortation that they should prepare their minds for action in $1 \mathrm{Pt} 1: 13$ ).

Flowing forth from studies of reality and the Word, the practical theologian becomes involved in the communication of God with people in a specific situation. For the people involved, the practical theologian acts as a facilitator to initiate this communication or to steer it into another direction. To do this, the researcher himself must start to talk to God and to the people; in addition, he has to be in touch with the reality of the people. Studying the Word in dependency of the Spirit - together with God's self-revelation both by mouth of the people in the relevant situation and by the course of the events - plays a determining role in this facilitation. ${ }^{7}$

\section{The diakonia of Practical Theology to alienated in South Africa in the light of 1 Peter}

From the above-mentioned research results, the following can be deduced about the diakonia of Practical Theology to the alienated in South Africa: Practical Theology means participating in Christ's diakonia to the Father for the sake of the world (see also Anderson 2001:40-42). The focus of Practical Theology is Christological.

The practical theologian as diakonos stands in the service of God in the first place and service to people remains an entailment of this primary focus. Practical Theology has a diaconal focus. 7.This view of Practical Theology supports both Heitink (1999:8-9), who describes
pastorate as a meeting event, and Thurneysen (1962), who emphasises preaching as the service of the Word for healing people. 
Practical theologians who have been made new by God are stewards of the rich grace of God and are sent by God to serve others with their gifts. The gifts are given by Christ and made to function in believers by the Spirit. Practical Theology has a Trinitarian focus.

This service work (diakonia) is amongst others, aimed at equipping those who feel alienated from their fatherland, South Africa; the aim is that the alienated should come to know and experience their identity in Christ. They have to arrive home in God's house in their hearts and thoughts. To achieve this, they must learn to prepare their minds to live as the sent ones of God on the grounds of the diakonia of the Triune God. Because of the grace they must live in such a way that everyone can see in their behaviour that they have been made new by God. Practical Theology has a missionary focus.

To equip people who feel alienated from their fatherland for some reason, practical theologians have to put themselves in those persons' shoes with priestly compassion. They have to take cognisance of the situation of those persons - their pain, disappointment and discouragement. They should not only tell them to stop complaining, as there are others whose situation is worse than theirs (Janse van Rensburg \& Pienaar 2005:49). Practical Theology has a pastoral focus.

In order to discover God as he revealed himself to people in the Old and New Testament, the Word of God must be exploited in such a way that the alienated in South Africa can experience him today as living, actively working and showing mercy. The diakonia of Practical Theology must lead people to God. Practical Theology has a missionary focus that is revelational-historical, that is, Gods revelation of himself in the history.

As congregants are servants of the grace of God, their involvement with alienated people must be exploited by research. ${ }^{8}$ The research of practical theologians must be utilised in congregations. How do we conduct a worship service so that those who are experiencing alienation may breathe freely in the gathering? How could they be brought to rejoice - with the other congregants - in the grace of God and worship him in song and praise? How do we organise the congregational ministry that the grace of God flows through the diakonia of the congregation to the alienated, thus creating living space and a home for them? What is the task of the leaders in the congregation in guiding the congregation in these matters? Practical Theology has an ecclesiological focus.

Researchers who truly want to be diakonos of God in their theology must prayerfully search for the wisdom of the Spirit. Practical theologians must be conscious of the fact that God is not only ministering to those who are experiencing alienation but also wants to use the alienated in his ministry. Researchers are therefore accountable to God for what they 8. Heitink (1999:285) calls congregational ministry oikodomics, which expresses something of the congregation as the family of God, a home for the alien. write or do. Practical Theology has a pneumatologicaleschatological focus, that is, to focus on the work of the Holy Spirit who is preparing the church for her future work in the world and for eternity.

Practical theologians must discover the reasons for alienation and, together with researchers from other subject fields, they must search for solutions. Together they should implement possible solutions, evaluate them in the light of feedback and refine or modify them entirely. Thus, researchers must accept the guidance of God that they receive through others who are involved and through the situation itself. Practical Theology has a pragmatic focus.

\section{Conclusion}

This article investigated the role that Practical Theology can play in addressing the problem of alienation amongst the people of South Africa. The investigation was conducted from the viewpoint of the biblical concept of diakonia (service work). This concept as well as the content of Practical Theology as it is found in the first letter of Peter was exegetically investigated with the purpose of elucidating the diakonia of Practical Theology with regard to alienation. It was found that practical theological research about the ministry to people, who feel alienated because of the previous and current situation in South Africa, can profit from the exegetical results of research on the diakon word group in the New Testament. Some guidelines were given as to how practical theological research could contribute to the ministry to the alienated in South Africa. It was further found that practical theological research's unique contribution to the issue of ministry to the alienated should come from a biblical perspective as distinct from a contribution that could as well have been from another discipline because of the lack of a biblical perspective. May this article lay the foundation for further research on the pastoral ministry to the alienated and on the leadership that is needed to address the problem of alienation in South Africa.

\section{Acknowledgements Competing interests}

The author declares that he has no financial or personal relationship(s) that may have inappropriately influenced him in writing this article.

\section{References}


org/10.1177/002096431106500109

Akinboade, O.A., Kinfack, E.C. \& Mokwena, M.P., 2012, 'An analysis of citizen satisfaction with public service delivery in the Sedibeng district municipality of South Africa', International Journal of Social Economics 39(3), 182-199. http:// dx.doi.org/10.1108/03068291211199350

Anderson, R.S., 1993, Ministry on the fireline, a practical theology for an empowered church, Wipf \& Stock, Eugene.

Anderson, R.S., 2001, The shape of Practical Theology: Empowering ministry with theological praxis, IVP Academis, Downers Grove.

Anderson, R.S., 2008, Minding God's Business, Wipe \& Stock, Eugene.

Arndt, W., Danker, F.W. \& Bauer, W., 2000, A Greek-English lexicon of the New Testament and other early Christian literature, 3rd rev. edn., University of Chicago Press, Chicago. (Based on Walter Baur's Griechisches- Deutsches Wörterbuch zu den Schriften des Neuen Testaments und der übrigen urchristlichen Literatur). 
Barry, S., 2006, 'Reconciliation: The South African Truth and Reconciliation Commission's contribution to dealing with the past, reconciling and building the Commission's contribution to dealing with the past, reconciling and building the
nation', In die Skriflig 40(4), 691-714. http://dx.doi.org/10.4102/ids.v40i4.365

Botha, J.G., 2004, 'Pastorale versorging van getraumatiseerde slagoffers van geweldmisdaad', PhD thesis, Department of Practical Theology, Faculty of Theology, North-West University, Potchefstroom.

Breed, G., 2012a, "n Begronde bedieningsmodel vir die diakonia van die gemeente', HTS Teologiese Studies/Theological Studies 68(2), 1-11.

Breed, G., 2012b, 'Nuut gedink oor die wese en inhoud van die dienswerk van die diaken', HTS Teologiese Studies/Theological Studies 68(1), 1-8.

Breed, G., 2013, 'Viva Vox Evangelii - Reforming Preaching. The preacher as diakonos according to John 12:26', in J. Hermelink \& A. Deeg (eds.), Viva vox evangelii reforming preaching, pp. 147-160, Evangelische Verlagsanstalt, Leipzig.

Breed, G. \& Breed, D.G., 2010, 'Besinning oor die diakonale dienswerk na aanleiding van Handelinge 6:1-7', In die Skriflig 44(3\&4), 627-653.

Breed, G. \& Du Plessis, A.L., 2012, 'A possible solution for corruption in South Africa with the church as initiator. A practical theological approach', paper delivered at the Joint Conference of Academic Societies in the Field of Religion and Theology, University of KwaZulu-Natal, Pietermaritzburg Campus, South Africa, 18-22 June.

Bruce, F.F., 1990, The Acts of the Apostles: The Greek text with introduction and commentary, Eerdmans, Grand Rapids.

Charles, R., 2010, 'Church and State in the "New" South Africa', Political Theology 11(6), 894-908. http://dx.doi.org/10.1558/poth.v11i6.894

Chiloane-Tsoka, E.G., 2012, 'Cultural Observations facing Women Managers: A South African Perspective', Gender \& Behaviour 10(2), 4949-4973.

Cilliers, J., 2013, 'Sacrament and sacredness: Perspectives on human dignity in South Africa', paper delivered at the annual meeting of the Society for Practical Theology in South Africa Potchefstroom, 23-25 January.

Clowney, E., 1988, The Message of 1 Peter. The way of the cross, Inter-Varsity Press, Illinois. (New Testament series).

Collins, J.N., 1990, Diakonia: Re-interpreting the Ancient Sources, Oxford University Press, Oxford.

Collins, J.N., 1992, Are all Christians ministers?, Liturgical Press, Collegeville.

Collins, J.N., 1995, 'A Ministry for tomorrow's church', Journal of Ecumenical Studies $32(2), 159-178$

Collins, J.N., 2002a, 'Contextualising Dorothea Reininger's Women Deacons', viewed 13 Oktober 2008, from http://www.womenpriests.org

Collins, J.N., 2002b, Deacons and the church: Making connections between old and new, Gracewing Publishing, Herefordshire.

Collins, J.N., 2005, 'Fitting lay ministries into a theology of ministry: Responding to an American consensus', Worship 79(2), 152-167

Collins, J.N., 2010, 'Re-thinking "eyewitnesses" in the light of servants of the word (Luke 1:2)', Expository Times 121(9), 447-452. http://dx.doi. org/10.1177/0014524610366500

Collins, J.N., 2012, 'A monocultural usage: Diakon- words in classical, Hellenistic, and patristic sources', Vigiliae christianae 55(3), 287-309.

Danaher, W.J., 2007, 'Towards a paschal theology of restorative justice', Anglican Theological Review 89(3), 359-373.

Elliot, J.H., 2000, 1 Peter: A new translation with introduction and commentary, Doubleday, New York.

Fagbemi, S.A.A., 2009, 'Living for Christ in a hostile world: The Christian identity and its present challenges in 1 Peter', Transformation: An International Journal of Holistic Mission Studies 26(1), 1-14. http://dx.doi.org/10.1177/0265378809102172

Goldin, J., 2002, 'Belonging to two worlds: The experience of migration', South African Psychiatric Review 5, 4-8.

Gooder, P., 2006, 'Diakonia in the New Testament: A Dialogue with John N. Collins', Ecclesiology 3(1), 33-56. http://dx.doi.org/10.1177/1744136606067678

Green, J.B., 2007, 1 Peter, The two Horizons New Testament commentary, Eerdmans, Grand Rapids.

Griffiths, C.G., 2007, 'Narratives of immigration: Negotiating transition', PhD thesis, Department of Theology, University of South Africa, Pretoria.

Gupta, N., 2009, 'A spiritual house of royal priests, chosen and honored: The presence and function of cultic imagery in 1 Peter', Perspectives in Religious Studies 36(1), 61-76.

Haddad, B., 2005, 'Reflections on the church and HIV/AIDS', Theology today 62(1), 29-37. http://dx.doi.org/10.1177/004057360506200104

Haire, J. \& Watson, G., 2003, 'Authority and integrity in the ministry of the church', Pronema 18, 29-53.

Hamilton, J.M., 2010, God's glory in salvation through judgement, a Biblical theology, Crossway, Weaton.

Heitink, G., 1999, Practical Theology: History, theory and action domains, Eerdmans, Grand Rapids.

Hentschel, A., 2007, Diakonia im Neuen Testament: Studien zur Semantik unter besonderer Berücksichtigung der Rolle von Frauen, Mohr Siebeck, Tübingen.
Horrel, D.G., 2007, 'The Label Xpıotıavóc: 1 Peter 4:16 and the formation of Christian identity', Journal of Biblical Literature 126(2), 361-381.

Ilo, S.C., 2009, 'Blacks against Blacks: Homelessness to Reconciliation', Afer 51(1-2), 78-104.

Janse van Rensburg, F., 2011, 'Constructing the economic-historic context of 1 Peter: Exploring a methodology', HTS Teologiese Studies/Theological Studies 67(1), 1-11.

Janse van Rensburg, J.J, 1992, 'The outline of 1 Peter, a reconsideration', Ekklesiastikos Pharos 74(1), 26-41.

Janse van Rensburg, J.J, 2000, 'Dekor of konteks? -Die verdiskontering van sosiohistoriese gegewens in interpretasie van 'n Nuwe Testament-teks vir die prediking en pastoraat geillustreer aan die hand van die 1 Petrus-brief', Skrif en Kerk 21(3), 564-582.

Janse van Rensburg, J.J., 2010, 'Die eskatologie van 1 Petrus: Hoop en vindikasie vir tydelike en permanente uitlanders', In die Skriflig 44(1), 201-228. http://dx.doi. org/10.4102/ids.v44i1.144

Janse van Rensburg, J.J. \& Pienaar, G., 2005, 'Vreemdeling in jou eie land? Teologiese riglyne vanuit 1 Petrus, met 'n juridiese begronding', In die Skriflig 39(1), 27-52.

Johnson, R.W., 1997, 'Acts 6:2-4, 7; 1 Peter-Recovery of passion in missiological concern', Review and Expositor 94, 599-603. http://dx.doi. org/10.1177/003463739709400410

Jeffrey, P., 2010, 'A Johannesburg church opens its doors. Room for refugees?', Christian Century, 20 April, pp. 22-25.

Joseph, A.P., 2012, 'A narralotological reading of 1 Peter', T\&T Clark, New York. (Library of New Testament Studies, 440).

Koelblea, T.A. \& LiPumab, A., 2010, 'Institutional obstacles to service delivery in South Africa', Social Dynamics 36(3), 565-589. http://dx.doi.org/10.1080/02533952.20 10.518002

Latvus, K., 2008, 'The Paradigm Challenged A New Analysis of the Origin of Diakonia', Studia Theologica 62, 142-157. http://dx.doi.org/10.1080/00393380802559816

Latvus, K., 2010, 'Diaconal Ministry in the Light of the Reception and Re-Interpretation of Acts 6. Did John Calvin Create the Social-Caritative Ministry of Diaconia?', Diaconia 1, 82-102.

Leer-Salvesen, P., 2009, 'Reconciliation without violence', Studia Theologica 63, 162177. http://dx.doi.org/10.1080/00393380903334598

Louw, D.J., 1999, Mature faith: Spiritual direction and anthropology in a theology of pastoral care and counseling, Peeters, Louvain.

Maluleke, T.S., 2005, 'Reconciliation in South Africa: Ten years later', Journal of Theology for Southern Africa 123, 105-120.

Marchetti-Mercer, M.C., 2012, 'Is it just about the crime? A psychological perspective on South African emigration', South African Journal of Psychology 42(2), 243-254.

McCruden, K.B., 2005, 'Compassionate Soteriology in Hebrews, 1 Peter, and the Gospel of Mark', Biblical Research 52, 41-56.

Meijers, E., 2009, 'White brothers--black strangers: Dutch Calvinist churches and apartheid in South Africa', Exchange 38(4), 365-380. http://dx.doi.org/10.1163/0 16627409X12474551163691

Meiring, P.G.J., 2009, 'Forward, with joy and confidence: Some thoughts on the prerequisites for reconciliation in South Africa', Journal of Theology for Southern Africa 134, 102-116.

Moobi, M.N. \& Oladele, O.I., 2012, 'Factors influencing small scale farmers' attitude and participation in formal financial markets in Mahikeng Municipality, South Africa', Journal of Human Ecology 39(1), 11-17.

Osmer, R., 2008, Practical theology: An introduction, Eerdmans, Grand Rapids.

Ponte, S., Roberts, S. \& Van Sittert, L., 2007, "Black Economic Empowerment", Business and the State in South Africa', Development \& Change 38(5), 933-955. http://dx.doi.org/10.1111/j.1467-7660.2007.00440.x

Shriver, D.W., Jnr., 2007, 'Repairing the past. Polarities of Restorative Justice', Cross Currents 57(2), 209-217.

Slaughter, J.R., 1995, 'The importance of literary argument for understanding 1 Peter', Bibliotheca Sacra 152, 72-91.

Sproul, R.C., 1997, What is reformed Theology? Understanding the basics, Baker Books, Grand Rapids.

Thurneysen, E., 1962, A Theology of pastoral care, John Knox Press, Richmond.

Vorster, J.M., 2009, 'Down memory lane to a better future', HTS Teologiese Studies/ Theological Studies 65(1), 1-6. http://dx.doi.org/10.4102/hts.v65i1.297

Vosloo, R., 2001, 'Reconciliation as the embodiment of memory and hope', Journal of Theology for Southern Africa 109, 25-40.

Williams, T.B., 2011, 'Reconsidering the imperatival participle in 1 Peter', Westminster Theological Journal 73, 59-78.

Williams, T.B., 2012, Persecution in 1 Peter. Differentiating and contextualizing early christian suffering, Brill, Boston. (Supplements to Novum Testamentum).

Zwemstra, J., 2003, 'Die kommunikatiewe funksies van die spore van Psalms in 1 Petrus', MA dissertation, Department of New Testament, Faculty of Theology North-West University, Potchefstroom. 